\title{
REASONS FOR CREATION AND PROCESS OF DEVELOPMENT OF PUBLIC ORGANIZATION «CONGRESS OF UKRAINIAN INTELLIGENCE»
}

\author{
Igor Yakovlev ${ }^{1}$ \\ Ilya Yunko ${ }^{2}$
}

DOI: https://doi.org/10.30525/978-9934-26-076-6-26

The Ukrainian intelligentsia was, is and will be a stronghold of Ukrainian patriotic thinking. It was the intelligentsia that defended the interests of the Ukrainian people in spite of everything. It has always struggled with the total onslaught of colonial neighbors and with an aggressive policy of planting foreign culture. History remembers hundreds of examples of the disobedience of the Ukrainian people, expressed both in the form of cultural protest and outright rebellion. History remembers hundreds of names of Ukrainian intellectuals who were not afraid to openly oppose totalitarianism and imperial chauvinism.

Almost immediately after independence, the Ukrainian information space was filled with Russian-language products that carried the agitation and propaganda necessary for the Kremlin's leaders. At a time when the corruption of domestic authorities is combined with the inability to resist Russian information aggression, and sometimes with their outright reluctance to do so, has led to a significant weakening of national consciousness among the citizens of Ukraine in the first years of independence.

Using the methods of agitation and propaganda and at the same time controlling a significant share of television, Moscow propagandists managed to formulate the image of Ukrainian nationalism in gloomy tones in a relatively short time. Drawing a constant analogy with Nazi Germany and Nazi Italy, playing on the feelings of World War II veterans, covering historical events only in one direction, they turned the notion of patriotism into the same as fascism. The Ukrainian language in a number of Ukrainian cities with a significant Russian-speaking population has become obsolete. Speaking Ukrainian was unprestigious and in some cases punished by condemning the Russian-speaking population.

All this was due to the fact that the vast majority of leaders in almost all government agencies were appointed to these positions by the Communist Party of the USSR. Being nationally unconscious and pursuing only the desire

\footnotetext{
${ }^{1}$ Odessa Polytechnic State University, Ukraine

${ }^{2}$ Odessa Polytechnic State University, Ukraine
} 
to satisfy their own interests, they were ready for anything, if only to prevent their replacement in office. The space scale corruption had appeared in the country at the same time.

The book publishing industry of Ukraine, which was already constantly suffering from oppression during the Soviet period, found itself in an even worse position after gaining independence. Printing in Ukrainian was not economically viable, not only was there little demand for such products, but competition from Russian producers, who flooded virtually all bookstore shelves with their products, led the Ukrainian people to choose to either read in Russian or not read at all.

Already in the first year of independence, along with new economic problems in the country, there was a threat of loss of national identity. Representatives of the Ukrainian intelligentsia, concerned about this problem, decided to oppose the aggressive actions of the Russian Federation. Unfortunately, their fragmentation did not allow to effectively resisting the total pressure on the information space of Ukraine. Of course, in many cities there were centers dissatisfied with the information policy of the new government, that is the lack of information security control, there were numerous speeches at rallies and forums on various national issues, but without the consolidation of all national and patriotic forces they had not ability to resist Russian aggression.

Therefore Ivan Fedorovych Drach as one of the main representatives of the cultural intelligentsia of Ukraine decided to intensify his socio-political activities and direct it to protect the rights and interests of the Ukrainian people. That is why he decides to create a Congress of the Ukrainian intelligentsia, a public organization whose vast majority of members would be representatives of the cultural, creative and scientific elite, that is, the intelligentsia.

I. Drach writes a manifesto in which he points out that: «the President of the Russian Federation in his Decree № 940 of September 14, 1995 on Russia's strategic course towards the CIS countries, according to which Ukraine is already considered a zone of Russia's national interests», " science. In fact, the National Academy of Sciences, which gave the world such outstanding scientists as Vernadsky, Hrushevsky, Palladin, Paton, Glushkov, and others, is being destroyed. Scientists, teachers, doctors, and cult educators are on the verge of physical survival. Unprecedented: the people have their own language, and most government officials speak the language of a foreign country, defiantly demonstrating «independence» from their own people. «But he strongly disagrees with the opinion that the Ukrainian idea did not work in Ukraine. This is a forgery of those for whom the proclamation of the sovereignty of our state is a «temporary phenomenon.» It was noted that the 
Ukrainian intelligentsia understands the inevitable objective difficulties of the first years of our independence. But he cannot accept the fact that we are being driven into a dead end of national non-existence. We will have enough resilience and self-sacrifice, as in previous generations, to prevent the overthrow of the great Ukrainian nation, which ranks fifteenth among hundreds of nations in the world. This is felt by Ukrainophobic government officials, who only change their anti-Ukrainian rhetoric without changing their anti-Ukrainian course. "We have retreated for too long, we have already surrendered many positions - we have been forced to disarm, our economy is being brought to its knees, but there is nowhere to retreat. For us, the holiest and most precious thing is Ukraine and its people» [1].

I. Drach tried to attract to the Congress the most influential representatives of the country's cultural elite, members of this organization from the first weeks of its existence were professors, scientists, artists, People's Deputies, and political figures but L. Kuchma made the greatest resonance in the political life of the Congress of Ukrainian Intelligentsia who spoke at the AllUkrainian Congress of Intellectuals with a report «We are not powerless in the face of the future» where he not only agreed with the ideas set out by Ivan Fedorovich in the Manifesto of the Ukrainian intelligentsia but also openly supported the Congress in the struggle for Ukraine's future. (Kuchma L., 1998). In addition to the President of Independent Ukraine, the first congress of the intelligentsia was attended by Patriarch of Russia and Ukraine Filaret, who also spoke in support of the intelligentsia in the protection of the rights and freedoms of the Ukrainian people. [2]

Cooperation between the intelligentsia and the government was mutually beneficial. On the one hand, I. Drach received from his allies the most influential ruler, who also stood on the positions of building a strong country. On the other hand, President Leonid Kuchma attracted the support of representatives of the Ukrainian intelligentsia, who had a certain influence on society and guaranteed him support in the next presidential election.

So we can conclude that due to the instability in the country's political life in the early 1990s, the Ukrainian people found themselves in a threatening situation, when their cultural and historical heritage was constantly attacked and oppressed by pro-Russian authorities. This state of affairs contributed to the consolidation of the Ukrainian cultural elite around the idea of I. Drach to create a public organization "Congress of Ukrainian Intelligentsia» whose main task was to protect the interests of the Ukrainian people, to build an independent, strong and prosperous Ukraine. Representatives of the «Congress of the Ukrainian intelligentsia» acted as leaders of the Ukrainian people to a better life, they began active cooperation with the authorities in order to implement the tasks assigned to them. Enlisting the support of the 
President of Independent Ukraine of that time Leonid Kuchma they managed to get into the Verkhovna Rada of Ukraine and occupy a number of important positions, which further influenced the development of Ukrainian statehood, which suggests that I. Drach managed to make a significant contribution to defending freedoms of the Ukrainian people.

\section{References:}

1. Drach I. (1995) Manifest Ukrayins'koyi Intelihentsiyi [Manifesto of the Ukrainian Intelligentsia]. Kyiv.

2. Drach I. (1998) Konhres Ukrayins'koyi Intelihentsiyi: materialy pershykh vseukrayins'ky khzborivintelihentsiyi [Congress of the Ukrainian Intelligentsia: materials of the first all-Ukrainian meeting of theintelligentsia]. Kyiv. 